\title{
Comparing qPCR and DNA methylation-based measurements of telomere length in a high-risk pediatric cohort
}

\author{
Waylon J. Hastings ${ }^{1}$, Laura Etzel ${ }^{1}$, Christine M. Heim ${ }^{1,2}$, Jennie G. Noll ${ }^{3}$, Emma J. Rose ${ }^{3,4}$, \\ Hannah M.C. Schreier ${ }^{1}$, Chad E. Shenk ${ }^{3,5}$, Xin Tang ${ }^{1}$, Idan Shalev ${ }^{1}$ \\ ${ }^{1}$ Department of Biobehavioral Health, The Pennsylvania State University, University Park, PA 16802, USA \\ ${ }^{2}$ Charité - Universitätsmedizin Berlin, Corporate Member of Freie Universität Berlin and Humboldt Universität zu \\ Berlin, Institute of Medical Psychology, Berlin, Germany \\ ${ }^{3}$ Department of Human Development and Family Studies, The Pennsylvania State University, University Park, PA \\ 16802, USA \\ ${ }^{4}$ The Edna Bennett Pierce Prevention Research Center, The Pennsylvania State University, University Park, PA \\ 16802, USA \\ ${ }^{5}$ Department of Pediatrics, The Pennsylvania State University College of Medicine, Hershey, PA 17033, USA
}

Correspondence to: Waylon J. Hastings, Idan Shalev; email: whastings2012@gmail.com, https://orcid.org/0000-0003-08752568; ius14@psu.edu

Keywords: telomere length, DNAmTL, qPCR, pediatric, agreement

Received: October 18, $2021 \quad$ Accepted: January 17, 2022

Published: January 24, 2022

Copyright: (c) 2022 Hastings et al. This is an open access article distributed under the terms of the Creative Commons Attribution License (CC BY 3.0), which permits unrestricted use, distribution, and reproduction in any medium, provided the original author and source are credited.

\begin{abstract}
Various approaches exist to assess population differences in biological aging. Telomere length (TL) is one such measure, and is associated with disease, disability and early mortality. Yet, issues surrounding precision and reproducibility are a concern for TL measurement. An alternative method to estimate TL using DNA methylation (DNAmTL) was recently developed. Although DNAmTL has been characterized in adult and elderly cohorts, its utility in pediatric populations remains unknown. We examined the comparability of leukocyte TL measurements generated using qPCR (absolute TL; aTL) to those estimated using DNAmTL in a high-risk pediatric cohort ( $N=269$; age: 8-13 years, $83 \%$ investigated for maltreatment). aTL and DNAmTL measurements were correlated with one another $(r=0.20, p=0.001)$, but exhibited poor measurement agreement and were significantly different in paired-sample $t$-tests (Cohen's $d=0.77, p<0.001$ ). Shorter DNAmTL was associated with older age $(r=-0.25, p<0.001)$, male sex $(\beta=-0.27, p=0.029)$, and White race $(\beta$ $=-0.74, p=0.008)$. By contrast, aTL was less strongly associated with age $(r=-0.13, p=0.040)$, was longer in males $(\beta=0.31, p=0.012)$, and was not associated with race $(p=0.820)$. These findings highlight strengths and limitations of high-throughput measures of TL; although DNAmTL replicated hypothesized associations, aTL measurements were positively skewed and did not replicate associations with external validity measures. These results also extend previous research in adults and suggest that DNAmTL is a sensitive TL measure for use in pediatric populations.
\end{abstract}

\section{INTRODUCTION}

Telomeres are repetitive nucleoprotein regions at chromosome ends that prevent end to end fusions and maintain chromosome stability [1]. Telomeres incrementally shorten each time a cell divides, leading to age-associated decreases in telomere length (TL) across the lifespan [2]. Large population studies have associated shorter TL with a range of health problems including cardiovascular disease, high blood pressure, cancer, and shorter life expectancy [3-5]. In addition, studies have shown that TL can be modulated by risk factors that are associated with shorter life expectancy, including substance abuse [6], poverty [7], and 
early-life adversity [8]. For these reasons, telomere attrition is considered a hallmark of biological aging [9]. Despite a plethora of literature relating TL to biological aging and disease processes [10], methodological and inferential challenges associated with their use have led to concerns about the validity of TL as a biomarker of aging [11].

Several methods for measuring TL have been developed, each with unique strengths and limitations [12]. Measurement of TL using Southern blot is widely regarded as a reliable method, providing an objective measure of average TL per chromatid end in kilobases $(\mathrm{kb})$ with high precision and reproducibility [13]. However, the Southern blot method is difficult to implement in epidemiological studies due to its reliance on high-quality concentrated DNA, the technical expertise needed to perform the assay, and limited throughput [14]. The most common method to quantify $\mathrm{TL}$ in epidemiological research is quantitative-PCR (qPCR), which expresses telomeric content $(\mathrm{T})$ relative to a single-copy gene $(\mathrm{S})$ via a unitless metric known as the $\mathrm{T} / \mathrm{S}$ ratio [15]. This technique requires substantially less DNA than Southern blot and is high-throughput, capable of analyzing over 100 samples on a single assay. Several iterations of the qPCR method have been introduced since its original development, including means of simultaneously estimating telomeric content and single-copy gene within the same well [16], as well as methods incorporating an oligomer standard-curve to approximate absolute TL (aTL) in kb [17].

Although widely used, concerns about the precision of TL measurement via qPCR remain. Several factors can influence $\mathrm{qPCR}$ precision, including DNA extraction method, sample storage conditions, and PCR mastermix, to name a few [18-20]. In one international collaborative study, the coefficient of variation $(\mathrm{CV})$ across replicate qPCR measurements ranged from $2.34 \%$ to $34.15 \%$, with an average of $18.31 \%$ [21]. Diminished assay precision makes it difficult to disentangle between-group differences from measurement error. For example, cross-sectional studies using the Southern blot method report between-group differences of a few dozen to several hundred base-pairs depending on the outcome tested [22-24]. With a lifespan range of TL near $12.5 \mathrm{~kb}$ to $4.5 \mathrm{~kb}[25,26]$, a low qPCR assay $\mathrm{CV}$ of $2 \%$ translates to measurement error of $90 \mathrm{bp}-250 \mathrm{bp}$, possibly obscuring meaningful differences between groups. Measurement error of this sort, combined with insufficient follow-up duration, may also contribute to the telomere lengthening conundrum sometimes observed in longitudinal studies $[27,28]$, a finding counter to studies using larger samples or Southern Blot techniques that report decreases in TL on the scale of $20 \mathrm{bp}-60 \mathrm{bp}$ per year [2, 29-31].

In response to ongoing concerns about the reliability of TL measurement via qPCR, alternative approaches have emerged, including a DNA methylation-based estimator of telomere length (DNAmTL) [32]. Although initially developed to predict TL measured by Southern Blot, DNAmTL exhibited superior mortality prediction and stronger associations with cardiovascular outcomes than TL measurements generated using Southern Blot [32]. Moreover, exceptionally long-lived individuals exhibited longer DNAmTL in the absence of such differences using TL measured via qPCR [33]. While DNAmTL has been validated using adult and elderly samples [34], its performance within pediatric cohorts remains unknown.

To address these gaps, we explored associations between TL measurements generated using both qPCR (aTL) and DNA methylation (DNAmTL) in a subset of participants from the ongoing Child Health Study (CHS). The CHS is a large multidisciplinary study designed to provide prospective, longitudinal data on the health and development of children with and without a history of maltreatment to better inform intervention research and reveal opportunities for reversibility [35]. We leveraged existing data from Time 1 (baseline) of the CHS to conduct cross-sectional analyses on the performance of each TL measure in relation to known metrics of external validity, as recommended for comparative studies [36]. Specifically, we examined each measure's ability to capture differences as a function of age, sex, race, and ethnicity [2, 37, 38], as well as each measure's responsiveness to early adversity, a life course exposure linked to accelerated biological aging and telomere attrition [8]. We also conducted exploratory analyses investigating associations with metrics less validated in pediatric populations, including paternal age effects [39] and concordance with pubertal development [40]. We predicted that both shorter aTL and shorter DNAmTL will be associated with older age, male sex, White race, exposure to maltreatment, advanced pubertal development and younger paternal age.

\section{RESULTS}

\section{Sample demographics}

Demographics for the analytical sample and distinguished by maltreatment versus comparison youth are shown in Table 1. No significant differences were observed in mean chronological age or distribution of sex, race, and ethnicity between the maltreatment and comparison groups. The maltreatment group did exhibit 
Table 1. Demographics for the analytical sample distinguished by investigation for maltreatment exposure.

\begin{tabular}{|c|c|c|c|c|}
\hline & Full Sample $(N=269)$ & Comparison $(N=47)$ & Maltreatment $(N=222)$ & \multirow{2}{*}{$p$-value } \\
\hline & Mean/\% (SD) & Mean/\% (SD) & Mean/\% (SD) & \\
\hline Age (years) & $11.38(1.47)$ & $11.13(1.49)$ & $11.43(1.47)$ & 0.210 \\
\hline BMI & $21.78(6.02)$ & $20.24(5.30)$ & $22.10(6.12)$ & $\mathbf{0 . 0 3 7}$ \\
\hline Income ( $\$ 10,000 /$ year $)$ & $3.75(3.47)$ & $5.77(3.95)$ & $3.33(3.22)$ & $<\mathbf{0 . 0 0 1}$ \\
\hline Tanner Stage & $2.44(1.05)$ & $2.06(1.01)$ & $2.52(1.04)$ & 0.007 \\
\hline Paternal Age at Birth (years) & $29.32(7.80)$ & $31.54(7.06)$ & $28.81(7.89)$ & 0.031 \\
\hline \multicolumn{5}{|l|}{ Sex } \\
\hline Male & $48.7 \%$ & $48.9 \%$ & $48.6 \%$ & \multirow{2}{*}{0.999} \\
\hline Female & $51.3 \%$ & $51.1 \%$ & $51.4 \%$ & \\
\hline \multicolumn{5}{|l|}{ Race } \\
\hline White & $68.4 \%$ & $80.9 \%$ & $65.8 \%$ & \multirow{3}{*}{0.053} \\
\hline Black/African American & $16.4 \%$ & $14.9 \%$ & $16.7 \%$ & \\
\hline Other & $15.2 \%$ & $4.3 \%$ & $17.6 \%$ & \\
\hline \multicolumn{5}{|l|}{ Ethnicity } \\
\hline Hispanic & $11.5 \%$ & $4.3 \%$ & $13.1 \%$ & \multirow{2}{*}{0.143} \\
\hline Non-Hispanic & $88.5 \%$ & $95.7 \%$ & $86.9 \%$ & \\
\hline DNAmTL (kb) & $8.04(0.18)$ & $8.07(0.16)$ & $8.03(0.19)$ & 0.191 \\
\hline aTL (kb) & $9.88(3.24)$ & $9.51(3.39)$ & $9.95(3.21)$ & 0.415 \\
\hline
\end{tabular}

significantly higher BMI, younger paternal age at birth, lower family income, and more advanced pubertal development.

\section{Concordance among TL measures and age- associated change in TL}

TL measurements estimated using qPCR were significantly longer than those estimated using DNA methylation in paired sample $t$-tests (Cohen's $\mathrm{d}=0.77$, $p<0.001$ ). Bland Altman analysis revealed a mean bias of $1.84 \mathrm{~kb}$ and wide limit of agreement ( -4.58 to 8.26 $\mathrm{kb})$. DNAmTL measurements fell within a narrower window, whereas aTL tended to overestimate the longest telomeres (Figure 1).

Both measures exhibited small but significant negative correlations with chronological age despite the narrow age range of the sample, with DNAmTL showing stronger associations (aTL: $\mathrm{r}=-0.13, p=0.040$; DNAmTL: $\mathrm{r}=-0.25, p<0.001$ ) (Figure 2; Table 2A). These associations translated to an average decrease of $273 \mathrm{bp}$ for each one-year increase in participant chronological age for the aTL measure, and $30 \mathrm{bp}$ decrease for each one-year increase in participant chronological age for the DNAmTL measure. Correlations between aTL and DNAmTL were also weak $(\mathrm{r}=0.20, p=0.001)$, but remained relatively unchanged following adjustment for chronological age (Table 2B). Sensitivity analyses with additional control for blood cell proportions resulted in slightly increased correlations among all measures (Supplementary Table 1).

We also tested for differences in TL measurements between older and younger participants distinguished using a median split of the sample $\left(\mu_{\text {YOUNG }}=10.13\right.$ years; $\mu_{\mathrm{OLD}}=12.63$ years). DNAmTL estimates were significantly shorter in older participants $(8.00 \mathrm{~kb}$ vs. $8.08 \mathrm{~kb}, p<0.001)$. aTL estimates were also shorter in older participants, but this difference was not statistically significant $(9.54 \mathrm{~kb}$ vs. $10.21 \mathrm{~kb}, p=0.09)$.

\section{Associations between TL measures and external validity metrics}

Both TL measures exhibited significant differences in mean value as a function of sex (Figure 3; Table 3). For DNAmTL, males exhibited significantly shorter TL relative to females $(8.02 \mathrm{~kb}$ vs. $8.06 \mathrm{~kb}, p=0.029)$. For aTL measures, the opposite trend was observed, with males exhibiting significantly longer TL relative to females (aTL: $10.40 \mathrm{~kb}$ vs. $9.36 \mathrm{~kb}, p=0.012$ ). Differences in TL as a function of racial groups were observed for the DNAmTL measure, with those identifying as White exhibiting significantly shorter TL relative to those identifying as Black/African-American 


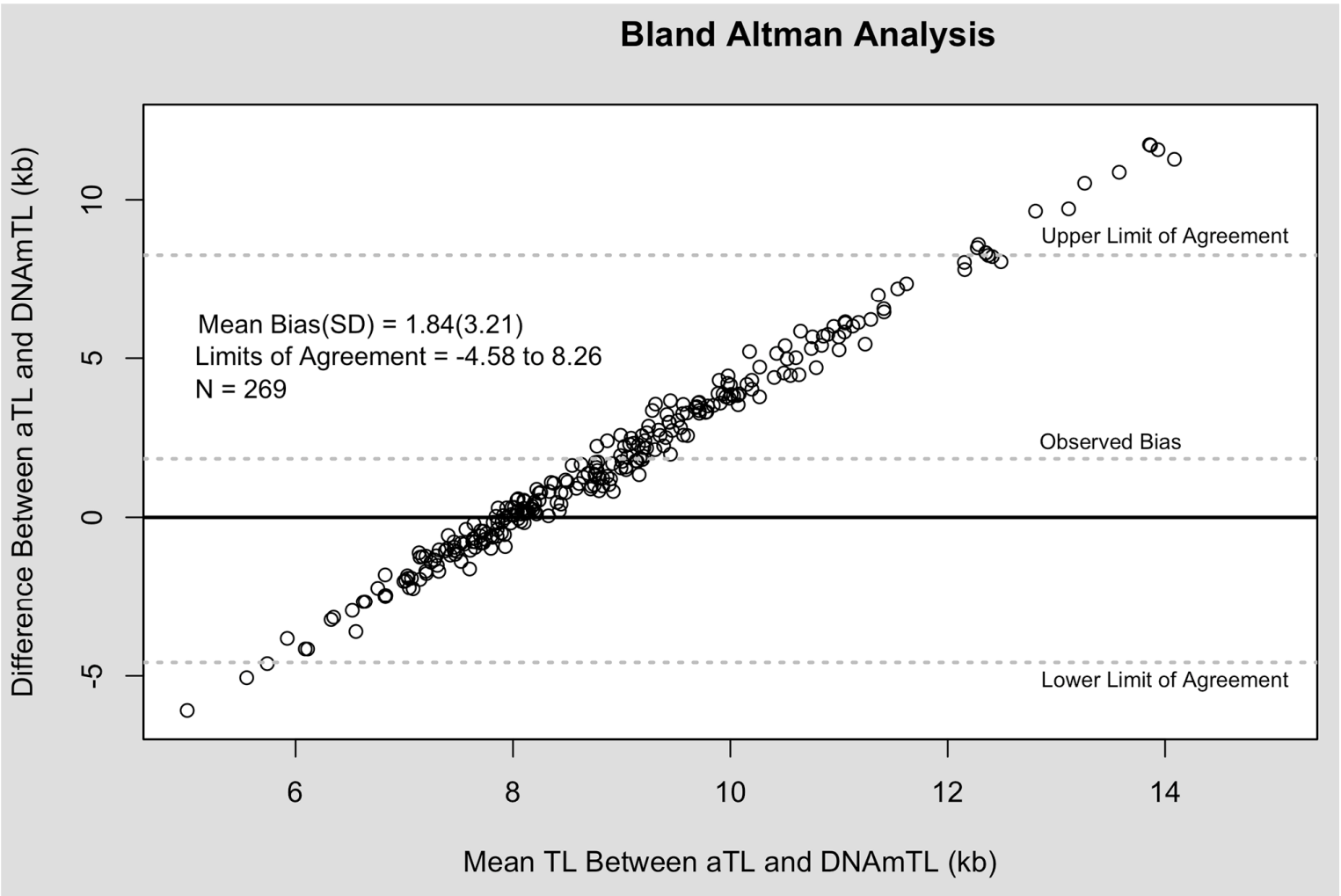

Figure 1. Bland Altman analysis of aTL and DNAmTL. X-axis represents the average of the two measures. The Y-axis represents the difference between the two measures. Each point corresponds to one paired comparison.

\section{Scatterplot of TL Measures and Chronological Age}
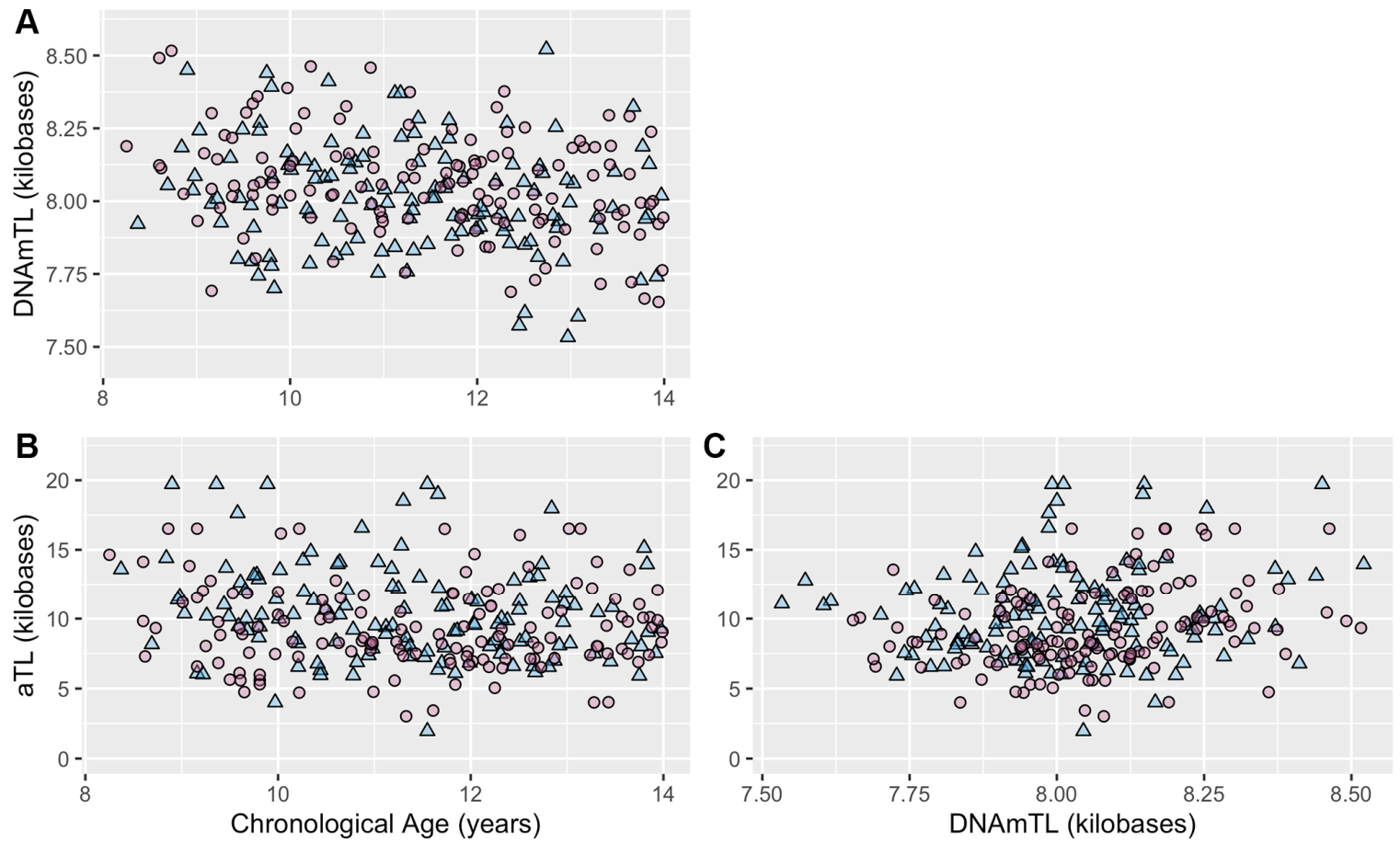

Sex $\bigcirc$ Female $\Delta$ Male

Figure 2. Scatterplots of chronological age and TL measures distinguished by sex. (A) DNAmTL and chronological age. (B) aTL and chronological age. (C) aTL and DNAmTL. Females and males distinguished by pink circles and blue triangles respectively. 
Table 2. Correlations among TL measures and chronological age before and after adjustment for chronological age. Statistic shown is Pearson correlation coefficient observed in partial correlation controlling for sex.

\begin{tabular}{|c|c|c|}
\hline \multirow[t]{2}{*}{$2 \mathrm{~A}$} & \multicolumn{2}{|c|}{ Raw Measures } \\
\hline & Age & DNAmTL \\
\hline DNAmTL & $-0.25^{* * *}$ & \\
\hline $\mathrm{aTL}$ & $-0.13^{*}$ & $0.20^{* *}$ \\
\hline \multirow[t]{2}{*}{ 2B } & \multicolumn{2}{|c|}{ Age-Adjusted Measures } \\
\hline & Age & DNAmTL \\
\hline DNAmTL & 0.00 & \\
\hline aTL & 0.00 & $0.18^{* *}$ \\
\hline
\end{tabular}

(A) correlation among raw TL measures. (B) Correlation among age-adjusted TL measures. Age-adjusted performed by extracting residuals of each TL measure regressed onto chronological age independently in males and females. ${ }^{*} p<0.05$; ${ }^{* *} p<0.01 ;{ }^{* * *} p<0.001$.

(8.01 kb vs. $8.13 \mathrm{~kb}, p=2.30 \mathrm{E}-05)$. By contrast, no differences across racial strata were observed in aTL measurements (Figure 3). For both measures, no differences were observed as a function of ethnicity or maltreatment exposure. Full models with additional covariate adjustments for blood cell proportion and demographic factors resulted in similar findings (Supplementary Table 2).

\section{Exploratory associations between TL measures, pubertal stage and paternal age}

We conducted exploratory analyses to test for associations between TL measures, pubertal development, and paternal age. Generalized estimating equation models revealed no associations between DNAmTL measurements and pubertal development

\section{Relationship Between TL Measures and Participant Demographics}

Race: 官 White/Caucasian

Black/African-American 官 Other

A

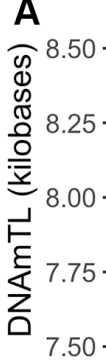

C

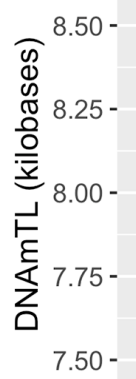

7.50
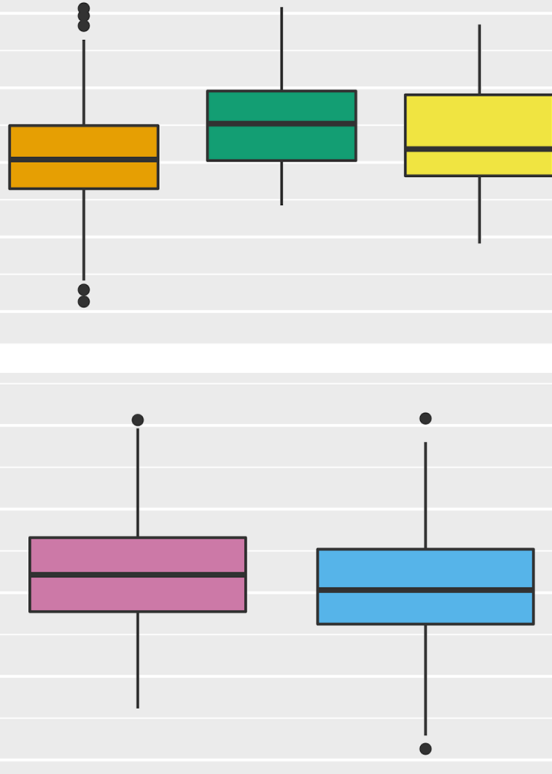

B

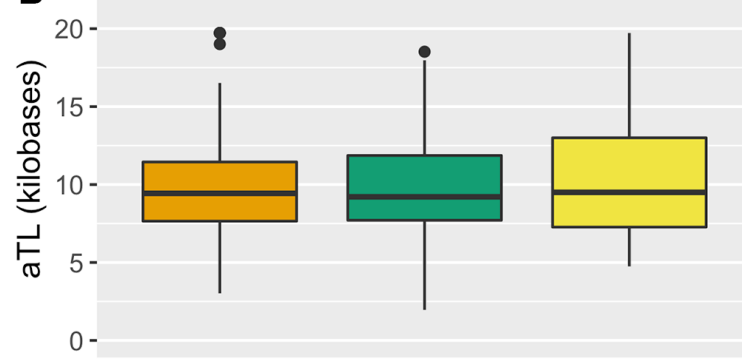

D

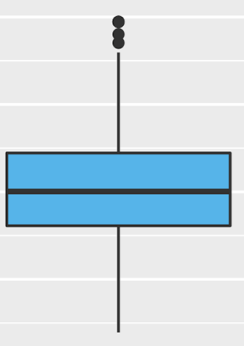

Sex:

Female

Male

Figure 3. Boxplots illustrating distribution of TL measures by participant demographic factors of race (top) and sex (bottom). (A) DNAmTL partitioned by racial status. (B) aTL partitioned by racial status. (C) DNAmTL partitioned by sex. (D) aTL partitioned by sex. 
Table 3. Results of generalized estimation equation models testing associations between TL measures and external validity metrics.

\begin{tabular}{|c|c|c|c|c|c|c|}
\hline \multirow[b]{3}{*}{ Biological Sex (Males vs. Females) } & \multicolumn{3}{|c|}{ DNAmTL } & \multicolumn{3}{|c|}{ aTL } \\
\hline & \multicolumn{3}{|c|}{$\beta[95 \% \mathrm{CI}] p$-value } & \multicolumn{3}{|c|}{$\beta[95 \% \mathrm{CI}] p$-value } \\
\hline & -0.27 & {$[-0.51,-0.03]$} & 0.029 & 0.32 & {$[0.07,0.56]$} & 0.012 \\
\hline Ethnicity (Hispanic vs. Non-Hispanic) & -0.15 & {$[-0.43,0.14]$} & 0.320 & -0.09 & {$[-0.58,0.41]$} & 0.730 \\
\hline Race (Black/African-American vs. White) & 0.74 & {$[0.44,1.03]$} & $<\mathbf{0 . 0 0 1}$ & -0.04 & {$[-0.37,0.29]$} & 0.820 \\
\hline Race (Other vs. White) & 0.28 & {$[-0.09,0.65]$} & 0.140 & 0.17 & {$[-0.21,0.55]$} & 0.370 \\
\hline Maltreatment (Exposed vs. Comparison) & -0.13 & {$[-0.41,0.14]$} & 0.330 & 0.16 & {$[-0.18,0.51]$} & 0.360 \\
\hline
\end{tabular}

Coefficients reflect standard deviation difference in age-adjusted TL between groups. All models included covariate control for chronological age. Models testing for differences in TL as a function of ethnicity, race, and maltreatment status included additional covariate control for sex. All models included random effect for family ID to account for partial nesting of siblings within families. Significant results in bold. Abbreviation: $\mathrm{Cl}$ : confidence interval.

Table 4. Results of generalized estimating equation models testing associations between TL measures and exploratory metrics.

\begin{tabular}{lcccccc}
\hline \multirow{2}{*}{ 4A } & \multicolumn{3}{c}{ Tanner Stage: Base Models } & \multicolumn{3}{c}{ Tanner Stage: Full Models } \\
\cline { 2 - 6 } & \multicolumn{3}{c}{$\boldsymbol{\beta}[\mathbf{9 5 \%} \mathbf{C I}] \boldsymbol{p}$-value } & $\boldsymbol{\beta}[\mathbf{9 5 \%} \mathbf{C I}] \boldsymbol{p}$-value \\
\hline DNAmTL & -0.04 & {$[-0.20,0.11]$} & 0.590 & -0.11 & {$[-0.24,0.02]$} & 0.111 \\
aTL & 0.15 & {$[0.00,0.30]$} & 0.051 & 0.14 & {$[-0.03,0.30]$} & 0.100 \\
\hline 4B & \multicolumn{3}{c}{ Paternal Age: Base Models } & \multicolumn{3}{c}{ Paternal Age: Full Models } \\
\cline { 2 - 6 } & \multicolumn{3}{c}{$\boldsymbol{\beta}[\mathbf{9 5 \%} \mathbf{C I}] \boldsymbol{p}$-value $[\mathbf{9 5 \%}$ CI] $\boldsymbol{p}$-value } \\
\hline DNAmTL & 0.01 & {$[-0.01,0.03]$} & 0.240 & 0.01 & {$[-0.01,0.02]$} & 0.408 \\
aTL & 0.00 & {$[-0.01,0.02]$} & 0.710 & 0.01 & {$[-0.01,0.02]$} & 0.510 \\
\hline
\end{tabular}

Age-adjusted TL measures were standardized within sex for analysis. Base models included covariate control for chronological age and sex. Full models included additional covariate control for blood cell proportions, BMI, income, race, and ethnicity. All models included random effect for family ID to account for partial nesting of siblings within families. (A) Models predicting measures of TL by Tanner stage. Coefficients reflect SD increase in age-adjusted TL for each one unit increase in Tanner stage. (B) Results of models predicting measures of TL by paternal age. Coefficients reflect SD increase in age-adjusted TL for each one-year increase in paternal age. Abbreviation: $\mathrm{Cl}$ : confidence interval.

measured using Tanner staging in both base and full models. Similarly, aTL measurements were not associated with pubertal development (Table 4A). Paternal age at birth was also not associated with either TL measure in base and full models (Table 4B).

\section{DISCUSSION}

We assessed the comparability of qPCR (aTL) and DNA methylation-based (DNAmTL) measures of TL in a high-risk pediatric cohort. Both measures exhibited expected decreases in TL with advanced chronological age. However, only DNAmTL replicated expected associations across external validity metrics, showing significantly shorter TL in males relative to females and White relative to Black/African-Americans. By contrast, aTL measures exhibited significant sex differences, but in the opposite direction from expectations.

The observed correlation between DNAmTL and aTL measures was positive and small $(\mathrm{r}=0.20, p=0.001)$, but within the range of values previously reported for studies investigating concordance between DNAmTL and qPCR-based measures (range $=-0.01-0.41$ ) [32, 34]. Notably, the previously reported correlation coefficients tended to be lower within datasets with the smallest age range $(r=-0.01$, age range $=3$ years; $\mathrm{r}=0.08$, age range $=4$ years), whereas datasets with a larger age range tended to be characterized by 
correlations of a higher magnitude $(\mathrm{r}=0.38$, age range $=57$ years; $r=0.41$, age range $=41$ years) $[32,34]$. Given the 5-year age range in the current study, the observed correlation between aTL and DNAmTL is of an expected magnitude given previously reported values.

Average TL for the analytical sample varied significantly between measures estimated using qPCR and those estimated using DNA methylation, with aTL estimates tending to be larger than those generated using DNAmTL. Despite differences between measures, observed sample means for both (aTL: 9.88 $\mathrm{kb}$; DNAmTL: $8.04 \mathrm{~kb}$ ) were within previously reported estimates generated by Southern blot, which tend to range between $7 \mathrm{~kb}$ to $10 \mathrm{~kb}$ for adolescents [30, 41]. Both measures were also significantly correlated with chronological age, although to a smaller degree than in previous reports. A large-scale meta-analysis including over 100 studies reported a pooled age correlation of $r=$ -0.29 for qPCR measures [42], and estimates for DNAmTL tend to be -0.60 or greater in magnitude [32, 34]. The modest correlations observed here may be a function of the relatively narrow age range for the current sample, which limits our ability to disentangle variability due to chronological age from interindividual variability at any given age. Even so, the observed decrease of $30 \mathrm{bp}$ per one-year increase in participant chronological age for DNAmTL estimates is similar to previous studies reporting decreases of 18 and 21 bp per year [32, 34], and is within 20-60 bp range typically observed for TL estimates generated using Southern blot and/or qPCR [2, 29-31]. By contrast, the 273 bp per year decrease estimated for aTL estimates was much larger than previous reports.

Previous work has highlighted limitations in the estimation of absolute TL in kilobases from qPCR measurements using conversion equations based on subsets of samples measured with more precise methods such as Southern Blot or flow FISH [43]. These limitations may be attributable to differences in the biochemical processes utilized in qPCR (i.e., exponentiation) relative to flow FISH or Southern Blot (i.e., hybridization), resulting in imprecise estimates for values at tails of the distribution when the relationship between methods is forcibly modeled linearly. For example, one should not expect accurate estimation of absolute TL in kilobases when the $\mathrm{R}^{2}$ for the correlation between T/S ratios and flow FISH TL is modest (e.g., $\mathrm{R}^{2}=0.56$ ). By contrast, the approach to generate aTL values in the current work relies only on qPCR data using double-stranded oligomer standards. This approach is advantageous in that the biochemical process by which standard concentrations are estimated is the same process by which samples are estimated, resulting in a significantly higher correlation between $\mathrm{T} / \mathrm{S}$ ratio values and aTL estimates $\left(\mathrm{R}^{2}=0.98\right)$. However, this approach is not without limitations. Specifically, the approach is challenged by the difficulty in accurately constructing oligomer standards with very low DNA concentrations. Slight deviations between expected and actual concentrations for these standards can result in under or overestimated aTL values, which may have occurred here.

Exploratory analyses failed to replicate hypothesized associations between TL measures and paternal age. Previous work, including a meta-analysis of nearly 20,000 participants, has shown evidence for a paternal age effect on TL in adulthood, where advanced paternal age is associated with longer TL in offspring [31, 39, 44]. Paternal age was also associated with salivary TL measured via the $\mathrm{T} / \mathrm{S}$ ratio in a cohort of children from New Zealand [38], but analyses were conducted without controls for age or sex. Therefore, it is possible that differences in TL resulting from paternal age do not manifest in leukocytes until later in life, or that associations between TL and paternal age are obscured by sex and age effects. We were also unable to distinguish differences in TL across pubertal development. The co-occurrence of accelerated pubertal development with accelerated biological aging has been contextualized as an evolutionary adaptation to earlylife adversity, wherein reproductive fidelity is prioritized at the cost of long-term survival to maximize the possibility of reproduction in a high stress environment [40]. Our work provides mixed support for this hypothesis. Individuals who were investigated for child maltreatment were characterized as having significantly advanced Tanner staging in the absence of any differences in chronological age. However, ageadjusted TL was not significantly associated with advanced pubertal development, irrespective if it was assessed via qPCR or DNA methylation. It may be that advanced pubertal development precedes changes in biological aging, and we intend to continue this analysis as the cohort expands with future waves of data collection and larger sample sizes.

Maltreatment exposure was not associated with accelerated biological aging in DNAmTL or aTL measurements. Features of the study design, such as how maltreatment was assessed, may have impacted our ability to detect these associations. A meta-analysis including 41 studies identified significant variation in the strength of associations with TL based on how adversity was evaluated [45]. Specifically, studies with a narrow focus on abuse and/or neglect tended to report lower effect sizes relative to studies with more comprehensive adversity assessment. Data collection for the CHS is still ongoing, and as a result we 
conducted analyses within a subset of the final cohort using both a dichotomous child maltreatment variable (investigated for maltreatment vs. comparison). As the remainder of the CHS cohort is assembled more detailed information is being collected from county level records for all participants, and future work with this cohort will be able to include more nuanced maltreatment variables. This is especially relevant for the DNA methylation-based indicator DNAmTL given recent evidence for the increased sensitivity of epigenetic aging measures to experiences of threat and violence relative to other domains of early adversity $[46,47]$.

We acknowledge limitations within the current study. Participant recruitment for the CHS is still ongoing, and a limited sample size for demographically matched comparison children may have also detracted from our ability to detect maltreatment effects in main analyses. Future analyses within the larger cohort will include more detailed maltreatment variables such as timing, duration, and severity of maltreatment, which may contribute to associations between early adversity and measures of cellular aging $[45,48]$. A lack of agreement between aTL and DNAmTL measures could also be attributed to processing differences in tissue source. Epigenetic data for DNAmTL was based on DNA extracted from whole blood using a magnetic bead protocol. By contrast, aTL measurements were generated on DNA extracted from buffy coat using a salting-out method. Although buffy coat cells make up the preponderance of leukocyte cells in whole blood, it remains possible that differences in the distribution of leukocyte cells or DNA extraction protocols could have contributed to differences between the two measures. The current findings are also limited by their crosssectional nature. It remains contentious as to whether static biological age or the rate of change in biological age across time is a better predictor of health and longevity [49-51]. Even so, inter-individual differences in TL established in early life may 'set the trajectory' for between-person differences across the lifespan [52]. Thus, it is uncertain whether the rate of telomere shortening or static TL better forecasts the future health of adolescents. The CHS offers an intriguing avenue to test these and other hypotheses related to the concordance among aTL and DNAmTL measures as future waves of data collection continue.

Overall, our findings highlight important limitations of high-throughput based measures of TL when applied within a pediatric cohort. In most instances, DNAmTL replicated associations with external validity metrics or showed effect sizes in the hypothesized direction. By contrast, aTL measurements were positively skewed and tended to exhibit relationships with few external validity measures. In sum, our findings extend previous research in adults and provide support for the utility of DNAmTL as a marker of biological aging for future research in pediatric populations.

\section{METHODS}

\section{Study design and sample recruitment}

Participants were drawn from the ongoing CHS, a large multidisciplinary study designed to provide prospective, longitudinal data on the health and development of children with and without a history of maltreatment. The CHS is recruiting a large statewide cohort of children exposed to maltreatment within the past 12 months, defined here as investigated reports of neglect, physical abuse, or sexual abuse, and demographically matched nonmaltreated comparison children aged 8-13 [35]. The goal of the CHS is to elucidate the multiple etiological processes believed to play a role in the onset and maintenance of adverse health outcomes among victims to better inform intervention research and reveal opportunities for reversibility. The Pennsylvania State University Institutional Review Board approved the study, and informed assent (child) and consent (caregiver) was obtained from all participants.

Children with a recent ( $<12$ months) report of maltreatment exposure were identified through Pennsylvania's Statewide Child Welfare Information System (CWIS). Subjects with recent involvement in the CWIS were invited to participate in the study through home mailings and phone contact by study coordinators. Eligibility for participation included: (1) aged 8 to 13 years, (2) subject of a CWIS maltreatment report (i.e., an allegation is made and investigated) within the past 12 months, and (3) agreement of participation by a non-abusing caregiver. Nonmaltreated comparison children are recruited via targeted advertisements from the same Pennsylvania counties as maltreated children with the goal of demographically matching at least one maltreated child based on age, race, ethnicity, sex, income level, and region within the State. Eligibility for participation includes: (1) no previous CWIS reports (i.e., via screening through CWIS prior to enrollment), and (2) demographic match to a maltreatment participant.

Cross-sectional data for the current study is drawn from Time 1 (baseline) assessment of currently enrolled CHS participants. Of the 439 participants who have completed Time 1, 401 consented to and successfully completed blood draws (the 38 missing blood samples included: 1 caregiver refusal, 33 participant refusals, 
and 4 attempted but incomplete blood draws). Of the 401 currently consented participants, 286 samples were available at the time of DNA methylation analyses, with 269 samples surviving DNA methylation and TL quality control metrics. Summary statistics for these participants are provided in Table 1 . We tested for differences between those missing DNA methylation and/or TL data $(N=170)$ and those with data for both measures $(N=269)$. In these analyses, the sample with incomplete data had significantly younger paternal age at birth relative to the analytical sample (27.63 vs. 29.32, $p=0.02$ ). No significant differences were detected for remaining demographic or covariate measures.

\section{Assessment of DNA methylation and calculation of DNAmTL}

During participants' visit, blood was collected by professional phlebotomists via venipuncture into two 10 mL EDTA tubes. A small volume of whole blood (3 $\mathrm{mL}$ ) was then aliquoted into a $4 \mathrm{~mL}$ EDTA tube and stored at $-80^{\circ} \mathrm{C}$ before DNA extraction and DNA methylation assays. DNA for methylation assays was extracted from whole blood using QIAsymphony (Qiagen, Germany). Epigenetic methylation assays were conducted using the Infinium methylation EPIC array (Illumina), which quantifies the methylation status of over 850,000 $\mathrm{CpG}$ and non-CpG sites. Resulting methylation measures were used to calculate DNAmTL according to published methods [32]. Briefly, the DNAmTL measure was developed by regressing leukocyte TL measured using Southern Blot onto blood methylation levels, and subsequently using elastic net regression to extract a final set of $140 \mathrm{CpGs}$ forming a predictive model. We extracted this set of $140 \mathrm{CpGs}$ and applied published regression coefficients to calculate DNAmTL measurements for participants in our analytical sample. Full details on sample processing and quality control for methylation analyses are provided in Supplementary Methods.

\section{Assessment of telomere length via qPCR and aTL calculation}

TL measurements generated using qPCR were determined based on DNA extracted from buffy coat cells. Buffy coat cells were isolated using centrifugation to separate plasma followed by treatment with $0.5 \times$ red blood cell lysis buffer (Invitrogen). Buffy coat cells were stored at $-80^{\circ} \mathrm{C}$ prior to DNA extraction using Gentra Puregene kits (Qiagen) with no modification from factory guidelines. DNA concentration was determined using Quant-iT PicoGreen Reagent (Qiagen). DNA purity and quality were assessed using $260 / 230$ and $260 / 280$ ratios for all samples $\left(\right.$ mean $_{260 / 230}$ $\left.=1.06 ; \operatorname{mean}_{260 / 280}=1.93\right)$. An additional subset of samples $(N=30 ; 11.1 \%)$ were evaluated using the Agilent 2200 TapeStation to determine the DNA Integrity Number (DIN) with mean $_{\text {DIN }}=8.6$, indicating intact, minimally degraded DNA.

TL assays were conducted following a qPCR method originally developed by O'Callaghan and Fenech [17] using a Rotor-Gene Q thermocycler connected to an uninterruptible power source (CyberPower), which has been shown to decrease variability in TL measured via qPCR [53]. Each qPCR assay was comprised of two runs, one quantifying telomere content $(\mathrm{T})$, and a second run quantifying genome copy number (S) using the single copy gene IFNB1. The two runs (T \& S) were always performed on the same day using the same DNA aliquot, which was stored at $4^{\circ} \mathrm{C}$ between runs $(\sim 2.5$ hours).

Raw fluorescence data was extracted from RotorGene Q software for post-processing using LinRegPCR [54]. Within LinRegPCR, individual windows of linearity were established for standards and analytical samples to estimate baseline DNA content $\left(\mathrm{N}_{0}\right), \mathrm{Cq}$ values, and amplification efficiency per amplicon (T or S) [55]. For aTL calculations, a conversion factor was generated as the average ratio of $\mathrm{N}_{0}$ estimates to expected concentration of the oligomer standards. $\mathrm{N}_{0}$ estimates for analytical samples were then divided by this conversion factor to estimate $\mathrm{kb}$ telomeric DNA and genome copy number for each sample, which were used for final calculation of aTL as:

$$
a T L=\frac{\text { Estimated } k b \text { Telomeric DNA }}{\text { Estimated Genome Copy Number } \times 92}
$$

To control for inter-assay variability, 3 control samples were assessed on each $\mathrm{T}$ run and each $\mathrm{S}$ run. The average inter-assay $\mathrm{CV}$ for control sample aTL estimates was $14.0 \%$. A random selection of 21 samples was reassessed for explicit purposes of calculating the interclass correlation coefficient (ICC), an indicator of measurement reliability. The resulting ICC for aTL estimates was 0.586 , indicating moderate reliability. Full details on qPCR assays for telomere length, including reaction mix composition and sequences for primers and standards, are summarized in Supplementary Table 3 in accordance with guidelines recommended by the Telomere Research Network (https://doi.org/10.31219/osf.io/9pzst).

\section{Pubertal development}

Pubertal development was assessed using Tanner staging, which indexes the development of physical 
traits on a five point scale ranging from 1 (prepubertal) through 5 (fully mature) [56-58]. Each participant rated their stage of pubic hair development and breast (females only) or testis (males only) development. The final pubertal development measure was calculated as the average across these two separate ratings.

\section{Other measures}

Chronological age, sex, race, ethnicity, and BMI were included as covariates due to known associations with TL. Sex was determined via self-report and crossvalidated using DNA methylation predicted sex. Two participants self-identified as 'other/transgender' but had not undergone any gender-reassignment treatment and were therefore coded as their cross-validated sex. Race was coded as 'White', 'Black/African American', or 'Other' (American Indian, Alaskan Native, Multiracial, or Other) based on reports provided by caregivers. Ethnicity was coded as either 'Hispanic' or Non-Hispanic'. BMI was measured as the total body mass in kilograms divided by the squared body height in meters. Family income was self-reported by caregivers as current total household income before taxes in increments of $\$ 10,000$ (e.g., under $\$ 10,000$ coded as ' 0 ', $\$ 10,000-\$ 19,999$ coded as ' 1 ', $\$ 20,000$ $\$ 29,999$ coded as ' 2 ' and an income over $\$ 120,000$ coded as ' 11 '). Differences as a function of maltreatment exposure were tested using a dichotomous variable that distinguished between those with CWIS maltreatment reports and those with no CWIS reports, i.e., maltreatment $(N=222)$ vs. comparison $(N=47)$. Paternal age at birth was determined using date of birth for the biological father and child where known. In instances where paternal date of birth was unknown $(N=11)$, it was approximated by subtracting the child's current age from the estimated current age of the biological father as reported by the current guardian.

\section{Statistical analyses}

Statistical analyses were performed using R Studio V 4.0.2. Tests for mean differences in demographic variables between maltreatment and comparison groups were assessed using two-tailed $t$-tests for continuous variables and two-way Chi-Square tests for categorical variables. We assessed continuous variables for skewness and kurtosis. Due to a subset of outlier measurements with values greater than 3 standard deviations above the mean ( $n=7)$, aTL measurements violated assumptions of normality ( skew $_{\text {aTL_pre }}=3.25$, kurtosisaTL_pre $=16.90)$. These 7 samples $(2.6 \%$ of the analytical sample) were winsorized at $3 \%$ of the upper tail prior to analyses, after which aTL measurements were approximately normal (skew aTL_post $=0.72$, kurtosis $_{\text {aTL_post }}=0.58$ ).
In order to compare measurement methods expressing $\mathrm{TL}$ in $\mathrm{kb}$ units, the current analyses utilized aTL measures generated using qPCR instead of the more commonly employed T/S ratio. Measurements of TL expressed using the $\mathrm{T} / \mathrm{S}$ ratio and aTL were highly correlated with one another $(\mathrm{r}=0.96, p<0.001)$, and exhibited similar associations across external validity and exploratory metrics. As a result, only analyses with aTL are shown here. Measurement agreement between aTL and DNAmTL was tested using Bland Altman analysis [59]. Measurement bias is estimated as the mean difference between the two methods, with a zeroline indicating perfect agreement. Limits of agreement are calculated as the area within two standard deviations of the mean difference.

Tests for differences in DNAmTL and aTL were conducted using versions of each measure adjusted for chronological age. Adjustment was performed by extracted non-standardized residuals of each measure regressed onto chronological age. To account for sex differences in TL, age-adjustment was performed independently in males and females. In instances when data for a given factor was unavailable for the full sample (i.e., Tanner stage and paternal age) ageadjustment was performed within the subsample with complete data for that factor $\left(\mathrm{N}_{\text {Tanner }}=265 ; \mathrm{N}_{\text {Paternal }}=\right.$ 223). These residuals were then standardized for use in generalized estimating equations to compute standardized effect sizes and $p$-values reported in text and tables. Group means in kilobases are provided to enhance interpretability of results. Tests for differences in age-adjusted DNAmTL and aTL were tested using generalized estimating equations (function geeglm). Base models included covariate adjustment for sex and chronological age only. Full models included additional covariate control for blood cell proportions estimated from methylation data using an established referencebased approach [60], as well as BMI, family income, race, and ethnicity. To account for partial nesting of siblings within families (4 families with three siblings, 3 families with two siblings, and 185 families with a single child), all models were estimated with standard errors clustered at the family level with family ID as the repeated factor.

Within our analytical sample, 4 individuals were missing covariate data for family income. No significant differences in other covariates were observed between these individuals and the remaining sample, and therefore missing data were addressed using multiple imputation and complete case analysis. We created 5 imputed datasets using IVEWare [61] and replaced missing values with the average of imputed values across these 5 iterations. Missing values for family income were imputed using all demographic variables. 


\section{AUTHOR CONTRIBUTIONS}

Study Design: Christine M. Heim, Jennie G. Noll, Emma J. Rose, Idan Shalev, Hannah M.C. Schreier, and Chad E. Shenk; Study conception: Waylon J. Hastings and Idan Shalev. Sample Acquisition: Xin Tang, Waylon J. Hastings, and Laura Etzel; Statistical Analysis: Waylon J. Hastings and Laura Etzel; Data interpretation and manuscript drafting: Waylon J. Hastings, Idan Shalev, and Laura Etzel; Manuscript critical review: All authors.

\section{CONFLICTS OF INTEREST}

The authors declare no conflicts of interest related to this study.

\section{FUNDING}

This study was supported by Eunice Kennedy Shriver National Institute of Child Health and Human Development (P50HD089922 to J.G.N), and the National Institute of Environmental Health Sciences (U01ES030949 to I.S.). L.E. was supported by National Institute on Aging T32 AG049676 to The Pennsylvania State University. Preliminary analyses were also supported by 2020 Pilot Research Award to W.J.H. from the Telomere Research Network (https://trn. tulane.edu). The content is solely the responsibility of the authors and does not necessarily represent the official views of the National Institutes of Health.

\section{REFERENCES}

1. Blackburn EH. Structure and function of telomeres. Nature. 1991; 350:569-73. https://doi.org/10.1038/350569a0 PMID: 1708110

2. Chen $\mathbf{W}$, Kimura $M$, Kim $S$, Cao $X$, Srinivasan $S R$, Berenson GS, Kark JD, Aviv A. Longitudinal versus cross-sectional evaluations of leukocyte telomere length dynamics: age-dependent telomere shortening is the rule. J Gerontol A Biol Sci Med Sci. 2011; 66:312-9.

https://doi.org/10.1093/gerona/glq223 PMID:21310811

3. Sanders JL, Newman AB. Telomere length in epidemiology: a biomarker of aging, age-related disease, both, or neither? Epidemiol Rev. 2013; 35:112-31.

https://doi.org/10.1093/epirev/mxs008

PMID:23302541

4. D'Mello MJ, Ross SA, Briel M, Anand SS, Gerstein H, Paré G. Association between shortened leukocyte telomere length and cardiometabolic outcomes: systematic review and meta-analysis. Circ Cardiovasc Genet. 2015; 8:82-90.

https://doi.org/10.1161/CIRCGENETICS.113.000485 PMID:25406241

5. Wang $Q$, Zhan $Y$, Pedersen NL, Fang F, Hägg $S$. Telomere Length and All-Cause Mortality: A Metaanalysis. Ageing Res Rev. 2018; 48:11-20. https://doi.org/10.1016/i.arr.2018.09.002 PMID:30254001

6. Pavanello $S$, Hoxha M, Dioni L, Bertazzi PA, Snenghi R, Nalesso A, Ferrara SD, Montisci M, Baccarelli A. Shortened telomeres in individuals with abuse in alcohol consumption. Int J Cancer. 2011; 129:983-92. https://doi.org/10.1002/ijc.25999 PMID:21351086

7. Hastings WJ, Shalev I, Belsky DW. Comparability of biological aging measures in the National Health and Nutrition Examination Study, 1999-2002. Psychoneuroendocrinology. 2019; 106:171-8. https://doi.org/10.1016/j.psyneuen.2019.03.012 PMID:30999227

8. Shalev I, Moffitt TE, Sugden K, Williams B, Houts RM, Danese A, Mill J, Arseneault L, Caspi A. Exposure to violence during childhood is associated with telomere erosion from 5 to 10 years of age: a longitudinal study. Mol Psychiatry. 2013; 18:576-81.

https://doi.org/10.1038/mp.2012.32 PMID:22525489

9. López-Otín C, Blasco MA, Partridge L, Serrano M, Kroemer G. The hallmarks of aging. Cell. 2013; 153:1194-217.

https://doi.org/10.1016/i.cell.2013.05.039

PMID:23746838

10. Shalev I, Entringer S, Wadhwa PD, Wolkowitz OM, Puterman E, Lin J, Epel ES. Stress and telomere biology: a lifespan perspective. Psychoneuroendocrinology. 2013; 38:1835-42. https://doi.org/10.1016/j.psyneuen.2013.03.010 PMID:23639252

11. Hastings WJ, Shalev I, Belsky DW. Translating Measures of Biological Aging to Test Effectiveness of Geroprotective Interventions: What Can We Learn from Research on Telomeres? Front Genet. 2017; 8:164.

https://doi.org/10.3389/fgene.2017.00164 PMID:29213278

12. Lai TP, Wright WE, Shay JW. Comparison of telomere length measurement methods. Philos Trans $R$ Soc Lond B Biol Sci. 2018; 373:20160451.

https://doi.org/10.1098/rstb.2016.0451

PMID:29335378 
13. Kimura M, Stone RC, Hunt SC, Skurnick J, Lu X, Cao X, Harley CB, Aviv A. Measurement of telomere length by the Southern blot analysis of terminal restriction fragment lengths. Nat Protoc. 2010; 5:1596-607. https://doi.org/10.1038/nprot.2010.124 PMID:21085125

14. Aubert G, Hills M, Lansdorp PM. Telomere length measurement-caveats and a critical assessment of the available technologies and tools. Mutat Res. 2012; 730:59-67.

https://doi.org/10.1016/i.mrfmmm.2011.04.003 PMID:21663926

15. Cawthon RM. Telomere measurement by quantitative PCR. Nucleic Acids Res. 2002; 30:e47. https://doi.org/10.1093/nar/30.10.e47 PMID: 12000852

16. Cawthon RM. Telomere length measurement by a novel monochrome multiplex quantitative PCR method. Nucleic Acids Res. 2009; 37:e21.

https://doi.org/10.1093/nar/gkn1027 PMID: 19129229

17. O'Callaghan NJ, Fenech M. A quantitative PCR method for measuring absolute telomere length. Biol Proced Online. 2011; 13:3.

https://doi.org/10.1186/1480-9222-13-3 PMID:21369534

18. Cunningham JM, Johnson RA, Litzelman K, Skinner $H G$, Seo S, Engelman CD, Vanderboom RJ, Kimmel GW, Gangnon RE, Riegert-Johnson DL, Baron JA, Potter JD, Haile R, et al. Telomere length varies by DNA extraction method: implications for epidemiologic research. Cancer Epidemiol Biomarkers Prev. 2013; 22:2047-54.

https://doi.org/10.1158/1055-9965.EPI-13-0409 PMID:24019396

19. Dagnall $\mathrm{CL}$, Hicks $B$, Teshome $K$, Hutchinson $A A$, Gadalla SM, Khincha PP, Yeager M, Savage SA. Effect of pre-analytic variables on the reproducibility of qPCR relative telomere length measurement. PLoS One. 2017; 12:e0184098. https://doi.org/10.1371/journal.pone.0184098 PMID:28886139

20. Jiménez KM, Forero DA. Effect of master mixes on the measurement of telomere length by GPCR. Mol Biol Rep. 2018; 45:633-8. https://doi.org/10.1007/s11033-018-4175-y PMID:29623565

21. Martin-Ruiz CM, Baird D, Roger L, Boukamp P, Krunic D, Cawthon R, Dokter MM, van der Harst P, Bekaert S, de Meyer T, Roos G, Svenson U, Codd V, et al. Reproducibility of telomere length assessment: an international collaborative study. Int J Epidemiol. 2015; 44:1673-83. https://doi.org/10.1093/ije/dyu191

PMID:25239152

22. Verhulst $S$, Dalgård $C$, Labat $C$, Kark JD, Kimura $M$, Christensen K, Toupance S, Aviv A, Kyvik KO, Benetos A. A short leucocyte telomere length is associated with development of insulin resistance. Diabetologia. 2016; 59:1258-65. https://doi.org/10.1007/s00125-016-3915-6 PMID:27020448

23. Valdes AM, Andrew T, Gardner JP, Kimura M, Oelsner E, Cherkas LF, Aviv A, Spector TD. Obesity, cigarette smoking, and telomere length in women. Lancet. 2005; 366:662-4.

https://doi.org/10.1016/S0140-6736(05)66630-5 PMID:16112303

24. Kurz DJ, Kloeckener-Gruissem B, Akhmedov A, Eberli FR, Bühler I, Berger W, Bertel O, Lüscher TF. Degenerative aortic valve stenosis, but not coronary disease, is associated with shorter telomere length in the elderly. Arterioscler Thromb Vasc Biol. 2006; 26:e114-7.

https://doi.org/10.1161/01.ATV.0000222961.24912.69 PMID: 16627805

25. Kimura M, Gazitt Y, Cao X, Zhao X, Lansdorp PM, Aviv A. Synchrony of telomere length among hematopoietic cells. Exp Hematol. 2010; 38:854-9. https://doi.org/10.1016/i.exphem.2010.06.010 PMID:20600576

26. Halaschek-Wiener J, Vulto I, Fornika D, Collins J, Connors JM, Le ND, Lansdorp PM, Brooks-Wilson A. Reduced telomere length variation in healthy oldest old. Mech Ageing Dev. 2008; 129:638-41.

https://doi.org/10.1016/i.mad.2008.07.004 PMID:18765247

27. Steenstrup T, Hjelmborg JV, Kark JD, Christensen K, Aviv A. The telomere lengthening conundrum-artifact or biology? Nucleic Acids Res. 2013; 41:e131.

https://doi.org/10.1093/nar/gkt370

PMID:23671336

28. Nettle D, Seeker L, Nussey D, Froy H, Bateson M. Consequences of measurement error in qPCR telomere data: A simulation study. PLoS One. 2019; 14:e0216118.

https://doi.org/10.1371/journal.pone.0216118 PMID:31042766

29. Steenstrup T, Kark JD, Verhulst $S$, Thinggaard $M$, Hjelmborg JVB, Dalgård C, Kyvik KO, Christiansen L, Mangino $M$, Spector TD, Petersen I, Kimura $M$, Benetos $\mathrm{A}$, et al. Telomeres and the natural lifespan limit in humans. Aging (Albany NY). 2017; 9:1130-42. 
https://doi.org/10.18632/aging.101216

PMID:28394764

30. Benetos A, Verhulst S, Labat C, Lai TP, Girerd N, Toupance S, Zannad F, Rossignol P, Aviv A. Telomere length tracking in children and their parents: implications for adult onset diseases. FASEB J. 2019; 33:14248-53.

https://doi.org/10.1096/fj.201901275R

PMID:31652401

31. Unryn BM, Cook LS, Riabowol KT. Paternal age is positively linked to telomere length of children. Aging Cell. 2005; 4:97-101.

https://doi.org/10.1111/i.1474-9728.2005.00144.x PMID:15771613

32. Lu AT, Seeboth A, Tsai PC, Sun D, Quach A, Reiner AP, Kooperberg C, Ferrucci L, Hou L, Baccarelli AA, Li Y, Harris SE, Corley J, et al. DNA methylation-based estimator of telomere length. Aging (Albany NY). 2019; 11:5895-923.

https://doi.org/10.18632/aging.102173 PMID:31422385

33. Gutman D, Rivkin E, Fadida A, Sharvit L, Hermush V, Rubin E, Kirshner D, Sabin I, Dwolatzky T, Atzmon G. Exceptionally Long-Lived Individuals (ELLI) Demonstrate Slower Aging Rate Calculated by DNA Methylation Clocks as Possible Modulators for Healthy Longevity. Int J Mol Sci. 2020; 21:615. https://doi.org/10.3390/ijms21020615 PMID:31963520

34. Pearce EE, Horvath S, Katta S, Dagnall C, Aubert G, Hicks BD, Spellman SR, Katki H, Savage SA, Alsaggaf R, Gadalla SM. DNA-methylation-based telomere length estimator: comparisons with measurements from flow FISH and qPCR. Aging (Albany NY). 2021; 13:14675-86.

https://doi.org/10.18632/aging.203126

PMID: $\underline{34083495}$

35. Schreier HMC, Heim CM, Rose EJ, Shalev I, Shenk CE, Noll JG. Assembling a cohort for in-depth, longitudinal assessments of the biological embedding of child maltreatment: Methods, complexities, and lessons learned. Dev Psychopathol. 2021; 33:394-408. https://doi.org/10.1017/S0954579420001510 PMID:33955343

36. Eisenberg DT. Telomere length measurement validity: the coefficient of variation is invalid and cannot be used to compare quantitative polymerase chain reaction and Southern blot telomere length measurement techniques. Int J Epidemiol. 2016; 45:1295-8.

https://doi.org/10.1093/ije/dyw191

PMID:27581804
37. Zhu H, Wang $X$, Gutin $B$, Davis $C L$, Keeton $D$, Thomas J, Stallmann-Jorgensen I, Mooken G, Bundy V, Snieder H, van der Harst $P$, Dong $Y$. Leukocyte telomere length in healthy Caucasian and African-American adolescents: relationships with race, sex, adiposity, adipokines, and physical activity. J Pediatr. 2011; 158:215-20.

https://doi.org/10.1016/i.jpeds.2010.08.007 PMID:20855079

38. Ly K, Walker C, Berry S, Snell R, Marks E, Thayer Z, Atatoa-Carr P, Morton S. Telomere length in early childhood is associated with sex and ethnicity. Sci Rep. 2019; 9:10359.

https://doi.org/10.1038/s41598-019-46338-x PMID:31316106

39. Broer L, Codd V, Nyholt DR, Deelen J, Mangino M, Willemsen G, Albrecht E, Amin N, Beekman M, de Geus EJ, Henders A, Nelson CP, Steves CJ, et al. Meta-analysis of telomere length in 19,713 subjects reveals high heritability, stronger maternal inheritance and a paternal age effect. Eur J Hum Genet. 2013; 21:1163-8. https://doi.org/10.1038/ejhg.2012.303 PMID:23321625

40. Belsky J, Shalev I. Contextual adversity, telomere erosion, pubertal development, and health: Two models of accelerated aging, or one? Dev Psychopathol. 2016; 28:1367-83.

https://doi.org/10.1017/S0954579416000900 PMID:27688015

41. Frenck RW Jr, Blackburn EH, Shannon KM. The rate of telomere sequence loss in human leukocytes varies with age. Proc Natl Acad Sci U S A. 1998; 95:5607-10. https://doi.org/10.1073/pnas.95.10.5607 PMID: 9576930

42. Müezzinler A, Zaineddin AK, Brenner H. A systematic review of leukocyte telomere length and age in adults. Ageing Res Rev. 2013; 12:509-19.

https://doi.org/10.1016/j.arr.2013.01.003 PMID:23333817

43. Wang $Y$, Savage $S A$, Alsaggaf $R$, Aubert $G$, Dagnall $C L$, Spellman SR, Lee SJ, Hicks B, Jones K, Katki HA, Gadalla SM. Telomere Length Calibration from qPCR Measurement: Limitations of Current Method. Cells. 2018; 7:183.

https://doi.org/10.3390/cells7110183

PMID:30352968

44. De Meyer T, Rietzschel ER, De Buyzere ML, De Bacquer D, Van Criekinge W, De Backer GG, Gillebert TC, Van Oostveldt P, Bekaert S, and Asklepios investigators. Paternal age at birth is an important determinant of offspring telomere length. Hum Mol Genet. 2007; 16:3097-102.

https://doi.org/10.1093/hmg/ddm271

PMID:17881651 
45. Ridout KK, Levandowski M, Ridout SJ, Gantz L, Goonan K, Palermo D, Price LH, Tyrka AR. Early life adversity and telomere length: a meta-analysis. Mol Psychiatry. 2018; 23:858-71.

https://doi.org/10.1038/mp.2017.26

PMID:28322278

46. Jovanovic T, Vance LA, Cross D, Knight AK, Kilaru V, Michopoulos V, Klengel T, Smith AK. Exposure to Violence Accelerates Epigenetic Aging in Children. Sci Rep. 2017; 7:8962.

https://doi.org/10.1038/s41598-017-09235-9

PMID:28827677

47. Sumner JA, Colich NL, Uddin M, Armstrong D, McLaughlin KA. Early Experiences of Threat, but Not Deprivation, Are Associated With Accelerated Biological Aging in Children and Adolescents. Biol Psychiatry. 2019; 85:268-78.

https://doi.org/10.1016/i.biopsych.2018.09.008 PMID:30391001

48. Marini S, Davis KA, Soare TW, Zhu Y, Suderman MJ, Simpkin AJ, Smith ADA, Wolf EJ, Relton CL, Dunn EC. Adversity exposure during sensitive periods predicts accelerated epigenetic aging in children. Psychoneuroendocrinology. 2020; 113:104484. https://doi.org/10.1016/i.psyneuen.2019.104484 PMID: $\underline{31918390}$

49. Belsky DW, Caspi A, Houts R, Cohen HJ, Corcoran DL, Danese A, Harrington $H$, Israel S, Levine ME, Schaefer JD, Sugden K, Williams B, Yashin Al, et al. Quantification of biological aging in young adults. Proc Natl Acad Sci U S A. 2015; 112:E4104-10.

https://doi.org/10.1073/pnas.1506264112 PMID:26150497

50. Belsky DW, Caspi A, Arseneault L, Baccarelli A, Corcoran DL, Gao X, Hannon E, Harrington HL, Rasmussen LJ, Houts R, Huffman K, Kraus WE, Kwon $D$, et al. Quantification of the pace of biological aging in humans through a blood test, the DunedinPoAm DNA methylation algorithm. Elife. 2020; 9:e54870.

https://doi.org/10.7554/eLife.54870

PMID: $\underline{32367804}$

51. Whittemore K, Vera E, Martínez-Nevado E, Sanpera C, Blasco MA. Telomere shortening rate predicts species life span. Proc Natl Acad Sci U S A. 2019; 116:15122-7.

https://doi.org/10.1073/pnas.1902452116

PMID: $\underline{31285335}$

52. Benetos A, Kark JD, Susser E, Kimura M, Sinnreich R, Chen W, Steenstrup T, Christensen K, Herbig U, von Bornemann Hjelmborg J, Srinivasan SR, Berenson GS, Labat C, Aviv A. Tracking and fixed ranking of leukocyte telomere length across the adult life course. Aging Cell. 2013; 12:615-21. https://doi.org/10.1111/acel.12086

PMID:23601089

53. Hastings WJ, Eisenberg DTA, Shalev I. Uninterruptible Power Supply Improves Precision and External Validity of Telomere Length Measurement via qPCR. Exp Results. 2020; 1:e52.

https://doi.org/10.1017/exp.2020.58

PMID: $\underline{3718773}$

54. Ramakers C, Ruijter JM, Deprez RH, Moorman AF. Assumption-free analysis of quantitative real-time polymerase chain reaction (PCR) data. Neurosci Lett. 2003; 339:62-6.

https://doi.org/10.1016/s0304-3940(02)01423-4 PMID: 12618301

55. Hastings WJ, Eisenberg DTA, Shalev I. Impact of Amplification Efficiency Approaches on Telomere Length Measurement via Quantitative-Polymerase Chain Reaction. Front Genet. 2021; 12:728603. https://doi.org/10.3389/fgene.2021.728603 PMID:34603389

56. Marshall WA, Tanner JM. Variations in pattern of pubertal changes in girls. Arch Dis Child. 1969; 44:291-303.

https://doi.org/10.1136/adc.44.235.291 PMID:5785179

57. Marshall WA, Tanner JM. Variations in the pattern of pubertal changes in boys. Arch Dis Child. 1970; 45:13-23.

https://doi.org/10.1136/adc.45.239.13

PMID:5440182

58. Petersen AC, Crockett L, Richards M, Boxer A. A self-report measure of pubertal status: Reliability, validity, and initial norms. J Youth Adolesc. 1988; 17:117-33.

https://doi.org/10.1007/BF01537962

PMID:24277579

59. Bland JM, Altman DG. Statistical methods for assessing agreement between two methods of clinical measurement. Lancet. 1986; 1:307-10.

https://doi.org/10.1016/S0140-6736(86)90837-8 PMID:2868172

60. Houseman EA, Accomando WP, Koestler DC, Christensen BC, Marsit CJ, Nelson HH, Wiencke JK, Kelsey KT. DNA methylation arrays as surrogate measures of cell mixture distribution. BMC Bioinformatics. 2012; 13:86.

https://doi.org/10.1186/1471-2105-13-86

PMID:22568884

61. Raghunathan TE, Solenberger PW, van Hoewyk J. IVEware: Imputation and Variance Estimation Software User Guide. Inst Soc Res Univ Michigan. 2002. 


\section{SUPPLEMENTARY MATERIALS}

\section{Supplementary Methods for DNA methylation}

\section{DNA extraction}

Genomic DNA was isolated from whole blood samples using a semi-automated approach (Qiasymphony, Qiagen). Genomic DNA purity and concentration was assessed using a nanophotometer (ImplenP300, Implen).

\section{DNA methylation analyses}

We used the Infinium methylation EPIC Beadchip (EPIC array, Illumina, San Diego CA, USA) to describe variation in DNA methylation across the genome. Genomic DNA (1ug) from whole blood was treated with sodium bisulfite using the Zymo EZ-96 DNA Methylation $\mathrm{Kit}^{\mathrm{TM}}$ (Zymo Research, Orange, CA, USA) with 200ng of bisulfite-treated DNA amplified, fragmented, and hybridized on the EPIC array. Samples were randomized across plates to avoid potential confounding between sources of technical variation and phenotypes of interest (e.g., maltreatment status). The resulting raw intensity values (idat files) are directly loaded into $\mathrm{R}$ for quality control and normalization using the Meffil package [1]. We used normalexponential out-of-band (noob) for background correction and dye-bias adjustment. Samples and probes with low signal intensity were removed. Concordance between predicted biological sex based on DNA methylation data and self-reported gender were verified for each sample with discordant samples removed.
Finally, we used a Bayes method (ComBat) to correct for sources of technical variation (i.e., slide) [2].

\section{Blood cell types}

Between samples differences in blood cell proportions were estimated using an established reference-based approach and included as covariates as needed for certain robustness checks [3].

\section{REFERENCES}

1. Min JL, Hemani G, Davey Smith G, Relton C, Suderman M. Meffil: efficient normalization and analysis of very large DNA methylation datasets. Bioinformatics. 2018; 34:3983-89. https://doi.org/10.1093/bioinformatics/bty476 PMID:29931280

2. Johnson WE, Li C, Rabinovic A. Adjusting batch effects in microarray expression data using empirical Bayes methods. Biostatistics. 2007; 8:118-27. https://doi.org/10.1093/biostatistics/kxj037 PMID: 16632515

3. Houseman EA, Accomando WP, Koestler DC, Christensen BC, Marsit CJ, Nelson HH, Wiencke JK, Kelsey KT. DNA methylation arrays as surrogate measures of cell mixture distribution. BMC Bioinformatics. 2012; 13:86. https://doi.org/10.1186/1471-2105-13-86 PMID:22568884 


\section{Supplementary Tables}

Supplementary Table 1. Partial correlations among TL measures and chronological age with additional control for blood cell proportions.

\begin{tabular}{lccc}
\hline A & \multicolumn{2}{c}{ Raw measures } \\
\cline { 2 - 4 } & Age & DNAmTL \\
\hline DNAmTL & $-0.26^{* * *}$ & $0.21^{* * *}$ \\
aTL & $-0.13^{*}$ & Age-adjusted measures & \\
\hline B & & & DNAmTL \\
\cline { 2 - 4 } & Age & $0.18^{* *}$ \\
\hline DNAmTL & 0.05 & & 0.00 \\
aTL & 0.00 & & \\
\hline
\end{tabular}

Partial correlations included control for sex as in main text with additional adjustment for lymphocyte, monocyte, and granulocyte proportions. Statistic shown is Pearson correlation coefficient. (A) Raw measures. (B) Age-adjusted measures. Age-adjusted performed by extracting residuals of each TL measure regressed onto chronological age independently in males and females. ${ }^{*} p<0.05 ;{ }^{* *} p<0.01 ;{ }^{* * *} p<0.001$.

Supplementary Table 2. Results of fully adjusted generalized estimation equation models testing associations between $\mathrm{TL}$ and external validity metrics.

\begin{tabular}{lccccccc}
\hline & \multicolumn{3}{c}{ DNAmTL } & \multicolumn{3}{c}{ aTL } \\
\cline { 2 - 7 } & \multicolumn{3}{c}{$\boldsymbol{\beta}[\mathbf{9 5 \%} \mathbf{C I}] \boldsymbol{p}$-value } & \multicolumn{3}{c}{$\boldsymbol{\beta}[\mathbf{9 5 \%} \mathbf{C I}] \boldsymbol{p}$-value } \\
\hline Biological Sex (Females vs. Males) & $\mathbf{- 0 . 3 5}$ & {$[-\mathbf{0 . 5 2},-\mathbf{- 0 . 1 2}]$} & $\mathbf{0 . 0 0 2}$ & $\mathbf{0 . 3 4}$ & {$[\mathbf{0 . 0 8 , 0 . 6 0 ]}$} & $\mathbf{0 . 0 1 0}$ \\
Ethnicity (Hispanic vs. Non-Hispanic) & -0.21 & {$[-0.48,0.06]$} & 0.123 & -0.17 & {$[-0.67,0.32]$} & 0.492 \\
Race (Black/African-American vs. White) & $\mathbf{0 . 5 1}$ & {$[\mathbf{0 . 2 4 , 0 . 7 7 ]}$} & $<\mathbf{0 . 0 0 1}$ & -0.17 & {$[-0.53,0.19]$} & 0.354 \\
Race (Other vs. White) & 0.12 & {$[-0.20,0.44]$} & 0.454 & 0.12 & {$[-0.26,0.50]$} & 0.547 \\
Maltreatment (Exposed vs. Comparison) & -0.19 & {$[-0.43,0.05]$} & 0.115 & 0.12 & {$[-0.26,0.50]$} & 0.549 \\
\hline
\end{tabular}

Coefficients reflect SD difference in age-adjusted TL between groups. All models included covariate control for chronological age, BMI, income, blood cell proportions, as well as sex, race, and ethnicity. All models included random effect for family ID to account for partial nesting of siblings within families. 


\section{Supplementary Table 3. TRN reporting guidelines.}

\begin{tabular}{|c|c|}
\hline Item & Description \\
\hline \multicolumn{2}{|c|}{ Sample type, storage, extraction, and integrity } \\
\hline Sample type & $\begin{array}{l}\text { DNA samples were extracted from buffy coat cells separated from whole blood collected in } 10 \mathrm{~mL} \text { EDTA tubes. Buffy coat cells were isolated } \\
\text { using centrifugation to separate plasma followed by treatment with } 0.5 \times \text { red blood cell lysis buffer (Invitrogen). }\end{array}$ \\
\hline Sample storage conditions & $\begin{array}{l}\text { Buffy coat cells were stored at }-80^{\circ} \mathrm{C} \text { in a solution buffer comprised of phosphate buffered saline } \mathrm{pH} 7.2+\text { EDTA }(2 \mathrm{mMol})+\text { bovine serum } \\
\text { albumin }(0.5 \%) \text { prior to extraction. Duration between sample collection and DNA extraction ranged from } 29 \text { days to } 2.17 \text { years (mean }=6.84 \\
\text { months; } \mathrm{SD}=4.80 \text { months). }\end{array}$ \\
\hline DNA extraction method & GentraPuregene (Qiagen) with no modification from factory guidelines. \\
\hline $\begin{array}{l}\text { DNA storage conditions, } \\
\text { including freeze-thaw cycles }\end{array}$ & $\begin{array}{l}\text { DNA was stored }-80^{\circ} \mathrm{C} \text { in Qiagen DNA Hydration Solution. On average there were three freeze thaws for DNA samples between extraction } \\
\text { and the qPCR assay. The first thaw was done to determine DNA concentration using Quant-iTPicoGreen reagent (Qiagen). PicoGreen assays } \\
\text { occurred in two batches. The first batch occurred between } 11 / 18 / 2019 \text { and } 12 / 23 / 2019 \text { with an average duration of } 7.68 \text { months between DNA } \\
\text { extraction and the PicoGreen assays. The second batch of PicoGreen assays occurred between } 8 / 21 / 2020 \text { and } 8 / 26 / 2020 \text { with an average } \\
\text { duration of } 0.97 \text { months between extraction and PicoGreen assays. } \\
\text { A second freeze thaw was needed to perform a dilution for the qPCR assay. The final thaw occurred when the sample was assayed. Samples } \\
\text { needing to be reassessed on qPCR assays ( } n=57 ; 21.1 \% \text { ) were thawed one additional time. DNA samples from the first batch of PicoGreen } \\
\text { assays were stored for an average of } 13.13 \text { months between the PicoGreen assay and qPCR assay. DNA samples from the second batch of } \\
\text { PicoGreen assays were stored for an average of } 4.52 \text { months between the PicoGreen assay and the qPCR assay. }\end{array}$ \\
\hline $\begin{array}{l}\text { Method of documenting DNA } \\
\text { quality and integrity }\end{array}$ & $\begin{array}{l}\text { DNA was quantified for all samples using Quant-iTPicoGreen Reagent (mean }=51.18 \mathrm{ng} / \mathrm{uL} \text { ). DNA purity and quality was assessed using } \\
260 / 230 \text { and } 260 / 280 \text { ratios for all samples. }\left(\operatorname{mean}_{260 / 230}=1.06 ; \text { mean }_{260 / 280}=1.93\right) \text {. An additional subset of samples }(n=30,11.1 \%) \text { were } \\
\text { evaluated using the DNA Integrity Number generated by the Agilent } 2200 \text { TapeStation with mean } \text { DIN }=8.6 \text {, indicating intact, minimally } \\
\text { degraded DNA. No exclusionary criteria was imposed prior to assays. }\end{array}$ \\
\hline $\begin{array}{l}\text { Percentage of samples } \\
\text { specifically tested for DNA } \\
\text { quality and integrity }\end{array}$ & $\begin{array}{l}\text { All samples were subjected to quality control via evaluation of } 260 / 280 \text { and } 260 / 230 \text { ratios. A subset of samples }(30 / 270=11.1 \%) \text { were } \\
\text { subjected to quality assessment via TapeStation. }\end{array}$ \\
\hline \multicolumn{2}{|l|}{ qPCR assay } \\
\hline $\begin{array}{l}\text { Method (qPCR, MMqPCR, } \\
\text { aTL, etc.) }\end{array}$ & $\begin{array}{l}\text { qPCR assays to calculate absolute telomere length (aTL) were structured such that each assay comprised two qPCR runs, one run quantifying } \\
\text { telomere content in kilobases (T) and a second run quantifying genome copy number (S) using the single copy gene } I F N B 1 \text {. The two runs (T \& S) } \\
\text { were always performed on the same day using the same DNA aliquot which was stored at } 4^{\circ} \mathrm{C} \text { between runs ( } 2.5 \text { hours). Each run hosted triplicate } \\
\text { reactions of } 21 \text { samples, } 6 \text { standards, } 3 \text { positive controls, and } 1 \text { no template control on } 100 \text { well disks. } \\
\text { A total of } 20 \text { qPCR assays were performed across a period of } 31 \text { days from } 12 / 16 / 2020 \text { to } 1 / 16 / 2021 \text { for analysis of all samples. }\end{array}$ \\
\hline PCR machine type & Qiagen Rotor-Gene Q using 100 well disks \\
\hline $\begin{array}{l}\text { Source of master mix and } \\
\text { reagents, and final reaction } \\
\text { volume }\end{array}$ & $\begin{array}{l}\text { The final reaction mix for the telomeric and IFNB1 reactions contains 1x QuantiTectSYBR Green Master Mix (Qiagen), } 0.2 \mathrm{U} \text { Uracil } \\
\text { Glycosylase (Thermo Fisher Scientific), } 0.1 \mathrm{uM} \text { forward primer, } 0.1 \mathrm{uM} \text { reverse primer, and } 6 \mathrm{ng} \text { DNA in a } 20 \mathrm{uL} \text { reaction. } \\
\text { Primers are purchased from IDT in lab-ready format (HPLC purified, 100uM in IDTE Buffer pH 8.0) }\end{array}$ \\
\hline $\begin{array}{l}\text { Telomere primer sequences } \\
\text { and concentration } \\
\text { Single copy gene name, primer } \\
\text { sequences, and concentration }\end{array}$ & $\begin{array}{l}\text { Forward Primer: 5'-CGGTTTGTTTGGGTTTGGGTTTGGGTTTGGGTTTGGGTT-3' } \\
\text { Reverse Primer: 5'-GGCTTGCCTTACCCTTACCCTTACCCTTACCCTTACCCT-3' } \\
\text { IFNB1 Forward Primer:5'-TGGCACAACAGGTAGTAGGCGACAC-3' } \\
\text { IFNB1 Reverse Primer:5'-GCACAACAGGAGAGCAATTTGGAGGA-3' }\end{array}$ \\
\hline $\begin{array}{l}\text { Full PCR program description } \\
\text { including temperature, times, }\end{array}$ & $\begin{array}{l}50^{\circ} \mathrm{C}-2 \mathrm{~min} \\
95^{\circ} \mathrm{C}-15 \mathrm{~min}\end{array}$ \\
\hline and cycle numbers & $\begin{array}{l}95^{\circ} \mathrm{C}-15 \mathrm{~s} \\
60^{\circ} \mathrm{C} \text { for } 1 \mathrm{~min} \\
72^{\circ} \mathrm{C} \text { for } 30 \mathrm{sec} \text { (data acquisition) }\end{array}$ \\
\hline & Melt $60^{\circ} \mathrm{C}$ to $99^{\circ} \mathrm{C}$ rising $1{ }^{\circ} \mathrm{C}$ per step with 5 sec per step \\
\hline $\begin{array}{l}\text { PCR efficiency of single copy } \\
\text { gene and telomere primers }\end{array}$ & $\begin{array}{l}\text { Estimates from RotorGene } \\
\text { Telo: } \mathrm{R}^{2}=0.999102(\text { range } 0.99401-0.9987 ; \text { Efficiency }=2.0465(\text { range } 2.00-2.09) \\
\text { IFNB1: } \mathrm{R}^{2}=0.999319(\text { range } 0.99793-0.99991) ; \text { Efficiency }=1.987(\text { range } 1.95-2.07) \\
\text { Estimates from LinRegPCR } \\
\text { Telo Amplicon Efficiency }=1.890 \\
\text { IFNB1 Amplicon Efficiency }=1.847\end{array}$ \\
\hline $\begin{array}{l}\text { Source and concentration of } \\
\text { control samples and standard } \\
\text { curve }\end{array}$ & $\begin{array}{l}3 \text { positive controls were randomly selected from within the sample to control for variation across T and S runs. Standards consisted of double } \\
\text { stranded oligomers purchased from IDT as lyophilized pellet with PAGE purification. } \\
\text { Standard curves for T runs consisted of } 84 \mathrm{bp} \text { double stranded oligomer comprised of } 16 \text { copies of canonical telomere repeat. Telomere Standard A } \\
\text { had concentration } 0.15 \mathrm{ng} / \mathrm{uL} \text {, which equates to } 5.86 \mathrm{e}+08 \mathrm{~kb} \text { telomeric DNA when } 4 \mathrm{uL} \text { is used in the qPCR assay. A series of } 1 / 10 \text { serial dilutions } \\
\text { were performed to generate a total of } 6 \text { standards for each T run comprising a range of } 5.86 \mathrm{e}+08 \text { to } 5.86 \mathrm{e}+5.86 \mathrm{e}+03 \mathrm{~kb} \text { telomeric DNA. } \\
\text { Standard curves for } \mathrm{S} \text { runs consisted of } 83 \mathrm{bp} \text { double stranded oligomer corresponding to the region of IFNB1 genomic DNA flanked by } \\
\text { IFNB1 primers. IFNB1 Standard } 1 \text { had concentration } 0.0005 \mathrm{ng} / \mathrm{uL} \text {, which equates to } 1.18 \mathrm{e}+07 \text { diploid genomes when } 4 \mathrm{uL} \text { is used in the } \\
\text { qPCR assay. A series of } 1 / 10 \text { serial dilutions were performed to generate a total of } 6 \text { standards for each S run comprising a range of } 1.18 \mathrm{e}+07 \\
\text { to } 1.18 \mathrm{e}+02 \text { diploid genome copies. }\end{array}$ \\
\hline $\begin{array}{l}\text { Telomere Standard Oligomer } \\
\text { Sequences }\end{array}$ & 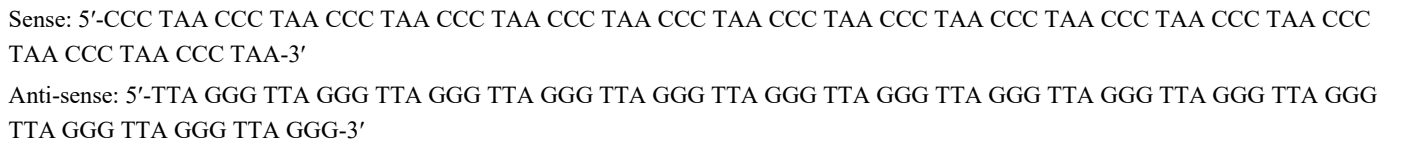 \\
\hline
\end{tabular}




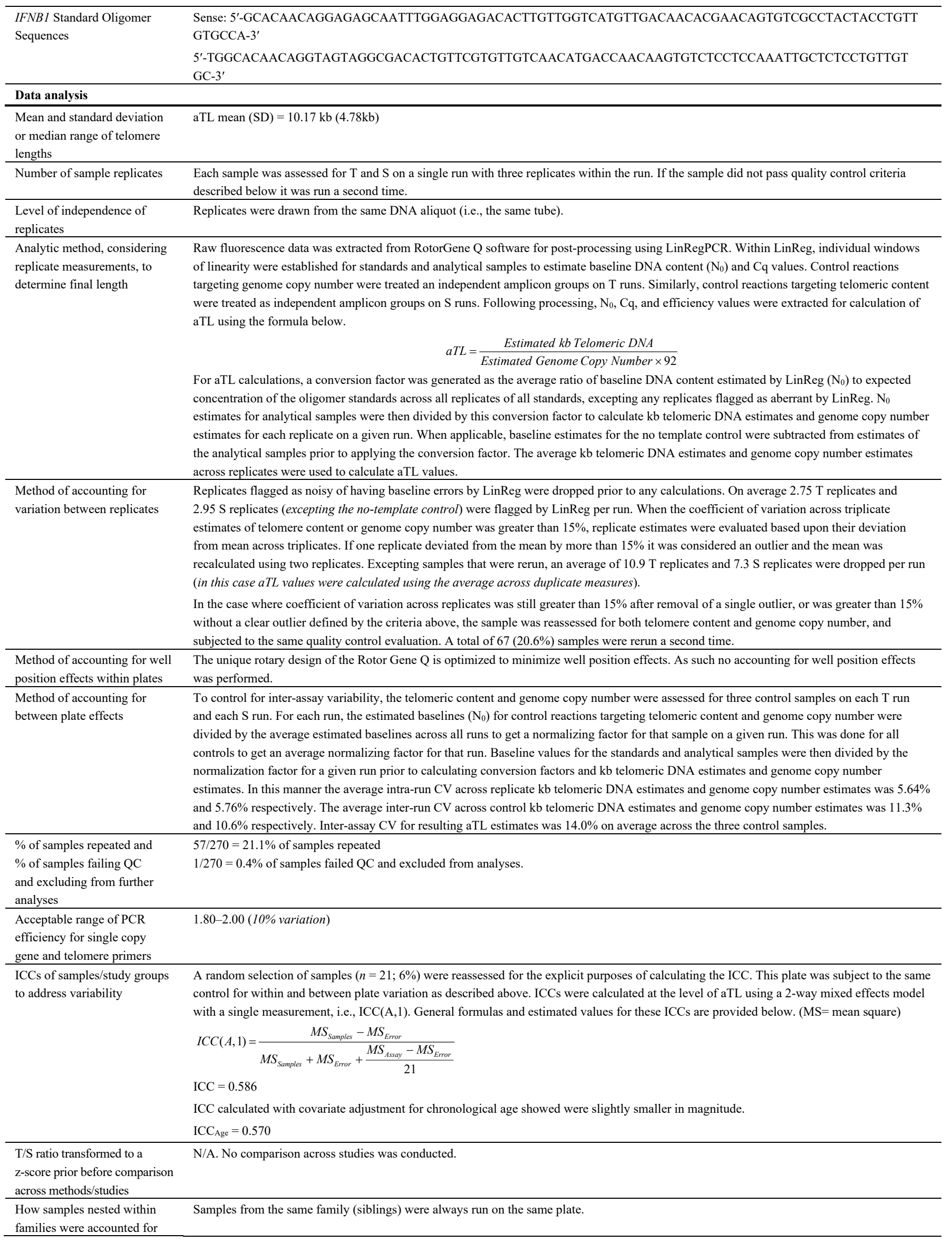

